\title{
OUTSIDER EDUCATION: INDIGENOUS LAW AND LAND-BASED LEARNING
}

\author{
John Borrows*
}

This article examines pedagogical developments in Canadian law schools related to outdoor education. In the process, it shows how recommendations from the Indian Residential Schools Truth and Reconciliation Commission can be applied, which called for law schools to create Indigenous-focused courses related to skills-based training in intercultural competency, conflict resolution, human rights and anti-racism. Land-based education on reserves can give law students meaningful context for exploring these Calls to Action. At the same time this article illustrates that taking students outside law school walls is not solely an Indigenous development. Thus, it first provides a few examples about how outdoor legal education is occurring in non-Indigenous settings. Next, the article examines unique Indigenous legal methodologies for learning law on and from the land. Finally, the author discusses his own experience in teaching Anishinaabe law on his reserve to demonstrate how students can develop deeper understandings of their professional responsibilities.

Dans cet article, l'auteur aborde les développements pédagogiques liés à l'enseignement de plein air dans les écoles de droit du Canada. Ainsi, il montre comment il est possible de donner suite aux recommandations de la Commission de vérité et de réconciliation relative aux pensionnats indiens, notamment en ce qui concerne la création par les écoles de droit de cours axés sur les compétences au regard de l'aptitude interculturelle, du règlement des différends, des droits de la personne et de la lutte contre le racisme. L'éducation axée sur le territoire qui est offerte sur les réserves peut donner aux étudiants en droit un contexte significatif qui les aidera à explorer ces appels à l'action. Au même moment, cet article montre que l'apprentissage du droit à l'extérieur des murs de l'école de droit n'est pas observé uniquement chez les Autochtones. Ainsi, l'auteur donne d'abord quelques exemples de la façon dont l'enseignement du droit à l'extérieur se fait dans des environnements non autochtones. Il décrit ensuite des méthodologies autochtones uniques utilisées pour l'apprentissage du droit axé et fondé sur le territoire. Enfin, l'auteur décrit l'expérience qu'il a lui-même vécue lorsqu'il a enseigné la loi anishinaabe sur sa réserve afin de démontrer comment les étudiants peuvent parvenir à mieux comprendre leurs responsabilités professionnelles.

\footnotetext{
Canada Research Professor in Indigenous Law, Faculty of Law, University of Victoria. The author is a member of the Chippewas of the Nawash Nation. I would like to thank the following individuals for their helpful suggestions on earlier drafts of this article: Deborah Curran, Karen Drake, Douglas Harris, John Kleefeld, Damien Lee, Aaron Mills, and Kerry Wilkins.
} 


\section{INTRODUCTION}

Legal education in North American once occurred outside the classroom. ${ }^{1}$ Before law schools were invented, students apprenticed under the supervision of experienced practitioners. ${ }^{2}$ They put in long hours. They learned through observation and practice. ${ }^{3}$ Periodic lectures punctuated their experience, though in most jurisdictions they occurred infrequently. Examinations, on the other hand, were more common. Accrediting bodies ensured candidates understood the foundations of their field. ${ }^{4}$ Credentials could be earned by degrees in some places. ${ }^{5}$ However, most education took place in proximity to senior members of the legal community. ${ }^{6}$ It did not happen in lecture halls or seminar rooms. As such, it was more attentive to customary law. ${ }^{7}$

Of course, I am talking about Indigenous legal education in North America prior to European arrival. ${ }^{8}$ Indigenous law was taught on the land and water. Elders and other law keepers supervised their initiates in context. Demonstration, observation, and practice formed the heart of learning. Lectures could occur, but emphasis was given to hands-on instruction. The form and substance of legal education was based on apprenticeships. Examinations were administered on a regular basis. Students were expected to recite songs, stories (cases), principles, teachings, and rules, in addition to demonstrating competence in ceremonial activities associated with the law. Degrees were awarded in societies; for instance, the Anishinaabe midewin society had a life-long continuing education program. ${ }^{9}$ Eight different degrees were awarded. They signified increasing power and expertise in Ojibwe law, as it was entwined with medicine, philosophy, and other areas of knowledge. ${ }^{10}$ Many of these systems still exist today. ${ }^{11}$ They

1 Karl N Llewellyn, with the contributions of E Adamson Hoebel, The Cheyenne Way: Conflict and Case Law in Primitive Jurisprudence (Norman, OK: University of Oklahoma Press, 1941).

2 The title for this task in Anishinaabemowin is "oshkaabewis." For a description about what is learned in this role, see Mary Siissip Geniusz, Plants Have So Much to Give Us, All We Have to Do Is Ask: Anishinaabe Botanical Teachings (Minneapolis: University of Minnesota Press, 2015). Mary was a traditionally trained apprentice of the late Keewaydinoquay. See Keewaydinoquay, Stories from My Youth (Lansing, MI: Michigan State University Press, 2006).

3 This is described in E Adamson Hoebel, The Law of Primitive Man (New York: Atheneum, 1974).

4 Selwyn Dewdney, The Sacred Scrolls of the Southern Ojibway (Toronto: University of Toronto Press, 1975).

5 William Berens, A Irving Hallowell \& Jennifer Brown, Memories, Myths, and Dreams of an Ojibwe Leader (Montreal and Kingston: McGill-Queen's University Press, 1991) at 164.

6 For examples, see Julie Cruikshank, Do Glaciers Listen? Local Knowledge, Colonial Encounters, and Social Imagination (Vancouver: UBC Press, 2005); William Robinson, as told by Walter Wright, Men of Medeek, 2nd ed (Kitimat, BC: Northern Sentinel Press, 1962); Jo-Anne Fiske \& Betty Patrick, Cis Dideen Kat (When the Plumes Rise): The Way of the Lake Babine Nation (Vancouver: UBC Press, 2000).

$7 \quad$ Fikret Berkes, Sacred Ecology: Traditional Ecological Knowledge and Resource Management (Philadelphia, PA: Taylor and Francis, 1999); Michael Angel, Preserving the Sacred: Historical Perspectives on the Ojibway Midewiwin (Winnipeg: University of Manitoba Press, 2002).

8 At the same time, many of the above practices were used to educate lawyers in Canada prior to the formation or widespread use of law schools. See Wes Pue, Law School: The Story of Legal Education in British Columbia (Vancouver: UBC Law School, 1995); Blaine Baker, "Legal Education in Upper Canada 1785-1889: The Law Society as Legal Educator" in David Flaherty, ed, Essays in the History of Canadian Law, vol 2 (Toronto: University of Toronto Press, 2012); Clifford Ian Kyer, The Fiercest Debate: Cecil A Wright, The Benchers, and Legal Education in Ontario 1923-1957 (Toronto: University of Toronto Press, 1997).

9 Walter James Hoffman, The Midewiwin, or “Grand Medicine Society”, of the Ojibwa in Smithsonian Institution, U.S. Bureau of Ethnology Report, vol 7 (Washington, DC: Government Printing Office, 1891) at 149-299.

10 Basil Johnston, Ojibway Ceremonies (Toronto: McClelland and Stewart, 1982). 
are a vibrant part of Canada's legal landscape. ${ }^{12}$ Unfortunately, most law students, lawyers, legislators, and judges never learn of their existence. This must change.

Legal education should more fully engage land-based contextual learning. ${ }^{13}$ This would be wise regardless of the legal tradition being taught, such as the common law, civil law, or Indigenous law. Furthermore, more can be done in relation to outdoor learning when teaching the place of Indigenous law in Canada. Indigenous legal reasoning is often related to the land. In fact, understanding how Indigenous peoples practise law as a land-based activity is required to appreciate Canada's Constitution. Indigenous law is an important source of authority for all Canadians in making decisions about our land and relationships. While some of this instruction can occur in the classroom, walls can hide important legal resources. Thus, law professors and students need to get outside more often. Again, this is true no matter the legal tradition. Indigenous legal education has something to offer North American law schools and the profession more generally. Participation and immersion in out-of-doors cultural contexts, even for short periods, can be very beneficial to learning. It also happens to be critical to understanding our broader place in this country.

This article discusses the importance of learning beyond the classroom in an Indigenous legal context. ${ }^{14}$ While university-based outdoor education is not unprecedented, ${ }^{15}$ it has been slow to develop in a law school environment. ${ }^{16}$ Law professors need to learn and apply this literature,${ }^{17}$ including its critiques. ${ }^{18}$ Learning on and from the land should be integral to understanding our legal world. Law lives "on the ground"; it is present in physical and social relationships. ${ }^{19}$ Positivistic declarations of

11 Eddie Benton-Banai, The Mishomis Book: The Voice of the Ojibway (St Paul, MN: Red School House Publishers, 1988).

12 John Borrows, Canada's Indigenous Constitution (Toronto: University of Toronto Press, 2010); K Akiwenzie-Damm, "We Belong to This Land: A View of 'Cultural Difference"" (1996) 31 Journal of Canadian Studies 21.

13 CF Black, The Land Is the Source of the Law: A Dialogic Encounter with Indigenous Jurisprudence (New York: Routledge, 2011).

14 For example, see Hadley Friedland, "Methods for Accessing, Understanding and Applying Indigenous Laws" (2012) 11 Indigenous Law Journal 1.

15 G Lowan, "Outward Bound Giwaykiwin: Wilderness Based Indigenous Education" (MA thesis, Lakehead University, Thunder Bay, ON, 2008) [unpublished]; G Lowan, "Exploring Place from an Aboriginal Perspective: Considerations for Outdoor and Environmental Education" (2009) 14 Canadian Journal of Environmental Education 42.

16 Guidance could be taken from Matthew Wildcat, Mandee McDonald, Stephanie Irlbacher-Fox \& Glen Coulthard, "Learning from the Land: Indigenous Land Based Pedagogy and Decolonization" (2014) 3 Decolonization: Indigeneity, Education and Society i.

17 Keith Thor Carlson, John S. Lutz \& David Schaepe, “Turning the Page: Ethnohistory from a New Generation” (2009) 2 University of the Fraser Valley Research Review 1; I Fuller et al, "International Perspectives on the Effectiveness of Geography Fieldwork for Learning" (2006) 30 Journal of Geography in Higher Education 89; Charles R Menzies \& Caroline F Butler, "Collaborative Service Learning and Anthropology with Gitxaała Nation" (2011) 4 Collaborative Anthropologies 169; K Castleden et al, "Settlers Unsettled: Using Field Schools and Digital Stories to Transform Geographies of Ignorance about Indigenous Peoples in Canada" (2013) 37 Journal of Geography in Higher Education 487.

18 Karin Nairn, “The Problems of Utilizing 'Direct Experience' in Geography Education” (2005) 29 Journal of Geography in Higher Education 293; M Hope, "The Importance of Direct Experience: A Philosophical Defense of Fieldwork In Human Geography" (2009) 33 Journal of Geography in Higher Education 169.

19 Russel Lawrence Barsh, "Coast Salish Property Law: An Alternative Paradigm for Environmental Relationships" (2008)14 Hastings West-Northwest Journal of Environmental Law and Policy 1375. 
Parliament and the courts are not law's only source. ${ }^{20}$ Legal obligations are generated in homes, businesses, hospitals, courts, cities, and rural landscapes. ${ }^{21}$ These and other legal sites should be explored and examined in more direct ways. Law professors can do more to mediate learning experiences in their immediate physical locations and much further afield.

In my view, land-based legal "site:ation" should take place in every law school across Canada. Law should be studied by directly experiencing and analyzing law's interactions with the physical world. Scepticism and hard questions should form a vital part of this work. ${ }^{22}$ This would be fully consistent with the development of professional legal skills required of lawyers, judges, and other legal actors. Such experiences are also consistent with law schools' liberal arts heritage. ${ }^{23}$ Learning in context should also help legal educators more fully embrace and critique insights from the sciences, humanities, and social sciences. ${ }^{24}$ When you are on the land, it is more difficult to isolate legal phenomena from their broader context. Legal reasoning cannot be as easily contained within the four-square pages of case law, statutes, and other written texts.

At the same time, a call for outdoor legal education should not be seen as undermining classroom experience. This kind of learning should not replace other important methods employed in law schools. ${ }^{25}$ Balance is a watchword in Indigenous legal education. Holistic learning is encouraged in most Indigenous pedagogies. Lectures and seminars are valuable in their own right. They provide efficient ways to explore how cases are constructed. They help us probe how broader background forces inform the development of cases, legislation, and regulatory decisions. Moot courts, negotiations, and other simulations are also important tools in gaining practice-ready, hands-on experience. In addition, clinical legal education programs are also essential in providing students with client-oriented education in a supervised setting. I have been in and around law schools for almost thirty years and participated in each

20 Brice Miller, “An Ethnographic View of Legal Entanglements on the Salish Sea Borderlands” (2014) 47 UBC L Rev 991.

21 Roderick Macdonald, Lessons of Everyday Law (Montreal and Kingston: McGill-Queen's University Press, 2002); Robert Ellickson, The Household: Informal Order around the Hearth (Princeton, NJ: Princeton University Press, 2090); Robert Ellickson, Order without Law: How Neighbors Settle Disputes (Cambridge, MA: Harvard University Press, 1994); Austin Sarat \& Thomas R Kearns, eds, Law in Everyday Life (Ann Arbor, MI: University of Michigan Press, 1995); Harry Arthurs, Without the Law: Administrative Justice and Legal Pluralism in Nineteenth-Century England (Toronto: University of Toronto Press, 1985).

22 Bruce Pardy, “Ontario's Policy Framework for Environmental Education” (2010) 22 Pathways: The Ontario Journal of Outdoor Education 22.

23 For a discussion of law from liberal arts perspectives, see Austin Sarat, ed, Law in the Liberal Arts (Ithaca, NY: Cornel University Press, 2004); Sherman Clark, "Law School as Liberal Education" (2013-2014) 63 Journal of Legal Education 235.

24 A prominent call for interdisciplinary legal education was found in Law and Learning by Consultative Group on Research and Education in Law (Ottawa: Social Sciences and Humanities Research Council of Canada, 1983). For an evaluation, see Constance Backhouse, "Revisiting the Arthurs Report Twenty Years Later" (2003) 18 Can J L \& Soc 33; Harry Arthurs \& Annie Bunting, "Socio-legal Scholarship in Canada: A Review of the Field" (2014) 41 J L \& Soc 487.

25 For a discussion of contemporary legal education and its possible futures, see William Sullivan et al, Educating Lawyers: Preparation for the Profession of Law (San Francisco: Jossey-Bass, 2007), which calls for the integration of three apprenticeships in legal education (theory, ethics, and practical skills); Canadian Bar Association (CBA), Legal Futures: Transforming the Delivery of Legal Services in Canada (Ottawa: CBA, 2014) at 54-63; Federation of Law Societies of Canada (FLSC), Task Force on the Canadian Common Law Degree, Final Report (October 2009), FLSC, <http://flsc.ca/wp-content/uploads/2014/10/admission8.pdf>. 
mode of learning as a professor and student. I have found each of these methods to be very important in generating sound legal education.

At the same time, despite these important tools and pedagogies, more needs to be done. An imbalance exists in legal education. Law is not just about ideas; it is a practice. The life of the law is experience. Students are denied a well-rounded legal education if they spend their entire three years indoors. The often isolating walls of a law school can breed an unhealthy insularity. Law students can miss vital insights if professors pay insufficient attention to "cases" that lie beyond their doors. Furthermore, student interest and engagement can be significantly heightened by field school moments.

In examining these issues, this article first discusses how law is currently being taught outdoors in a few notable examples. Second, it examines how Indigenous legal methodologies contain somewhat unique insights for learning law on and from the land. Third, I discuss my own experience in teaching Anishinaabe law in an outdoors context to demonstrate how students can develop deeper understandings of their professional responsibilities. In this regard, I consider the group phenomena of Indigenous law camps and the individual experiences of guided study in more isolated settings. Throughout this article, the central place of telling stories in outdoor locations as a means of recording and transmitting law is never far from the surface.

\section{LAW FROM AN “OUTSIDERS”' PERSPECTIVE: CURRENT EXAMPLES OF OUTDOOR LEGAL EDUCATION}

First, it is important to emphasize that Indigenous legal educators are not alone in teaching outdoors. ${ }^{26}$ Outsider education is certainly not just an Indigenous legal phenomenon. There are some prominent examples of law school professors developing courses and programs that attend to outdoor legal education. For example, Doug Harris in the Faculty of Law at the University of British Columbia [UBC] teaches property law with an outdoor component. I remember seeing early signs of this approach when I taught at UBC many years ago. Doug was a doctoral student at the time. He took his graduate student colleagues and professors on a trip down the Fraser River. He organized the class with Sto:lo scholar and educator, Sonny McHalsie (Naxaxalhts'i). ${ }^{27}$ McHalsie explained the Coast Salish legal world by reference to the river, mountains, forests, insects, birds, and animals encountered along the way. ${ }^{28}$ Sonny showed us historic village sites and explained the community's current relationship with all parts of their territory. We saw transformer figures and embodied ancestors in and among the rocks, fields, and forests. Sonny told us what they represented. He recounted their life's experiences. He drew principles from these experiences and illustrated how they are used for regulating conduct and resolving

26 Michelle Richmond-Saravia, The Significance of the Land in the Education and Health of Anishinaabe Youth from Pic River First Nation (MA thesis, Lakehead University, 2012) <http://www.giftsfromtheelders.ca/pdf/thesis_michelle_r_saravia.pdf> [unpublished].

27 An example of McHalsie's work is found in Albert (Sonny) McHalsie, "We Have to Take Care of Everything That Belongs to Us," in Bruce Miller, ed, Be of Good Mind: Essays on the Coast Salish (Vancouver: UBC Press, 2007) 85.

28 For a scholarly account of Sto:lo territory, see Keith Thor Carlson, ed, A Stó:lō-Coast Salish Historical Atlas (Vancouver, BC: Douglas and McIntyre, 2001). 
disputes. ${ }^{29}$ He helped us see the "cases" that lay on the land before us. Stories formed a large part of his teaching. McHalsie reinforced Sto:lo presence on the land by recounting how these stories continued to communicate specific norms and standards for living well in the world.

After a ground-breaking dissertation, Doug graduated with distinction. He was eventually hired as a professor at the law school where he continued to find ways to work with law through outdoor legal education. For example, over the past ten years, Doug has taken his first-year property law students to sites of key cases studied in the classroom. Doug's first destination is often False Creek in downtown Vancouver. He and his students walk the boundary of the former Kitsilano Indian Reserve. In the process, he discusses the broader political and legal forces that dispossessed and recently repatriated ten acres of land to local First Nations in a 2002 British Columbia Court of Appeal decision. ${ }^{30}$ This experience eventually helped Doug write a law review article that considers property and sovereignty in British Columbia through understanding the legal history of the former Kitsilano Reserve. ${ }^{31}$

Harris also walks along a portion of the Arbutus rail corridor with his students. ${ }^{32}$ This is the site of the Supreme Court of Canada's most recent statement on the doctrine of regulatory takings. ${ }^{33}$ As he discusses the case, he explains how property is both a communal and individuated interest. After visits to these locations, Doug moves on to Granville Island. Here, he talks about the condominium forest that has emerged around the inlet. ${ }^{34}$ In working through the city in this way, Harris states:

There are all sorts of good pedagogical reasons for doing the trips, or at least I think there are. Mostly I do them because they're good fun for me and, I think, for the students. One year, Frank Iaccobucci joined us on the field trip after he had retired from the SCC. It was a wet, windy November and we (a group of about 35 or 40) were huddled under the Burrard Street Bridge, trying to stay out of the rain. It was the site of the former Coast Salish village of Snauq, on the boundary of the current Kitsilano reserve, with a homeless person's shelter made of cardboard and plastic behind us, and Justice Iacobucci, standing in wet running shoes, responding to a student's question about the importance of the rule of law. It was a moment I'll never forget, and I don't think the students will either. I suspect none of us would still remember a lecture on the subject in the classroom. In fact, the moment couldn't have happened in the classroom. ${ }^{35}$

29 For a discussion of Sto:lo law that draws from the land, see Ted Palys \& Winona Victor, "Getting to a Better Place: Qwi:qwelstom, the Sto:lo, and Self-Determination" in Law Commission of Canada, Indigenous Legal Traditions (Vancouver: UBC Press, 2007) 12.

30 Canada (Attorney General) v Canadian Pacific Ltd, 2002 BCCA 478 (CanLII).

31 Douglas Harris, "Property and Sovereignty" (27 November 2015) (on file with author). See also Jean Barman, "Erasing Indigeneity in Vancouver" (2007) 155 BC Studies 2.

32 Douglas Harris, "A Railway, a City and the Public Regulation of Private Property: C.P.R. v. The City of Vancouver" in E Tucker, B Ziff, \& J Muir, eds, Canadian Cases in Context (Toronto: Osgoode Society for Canadian Legal History and Irwin Law, 2012) 455.

33 Canadian Pacific Railway Co v Vancouver (City), [2006] 1 SCR 227.

34 Douglas Harris, "Condominium and the City: The Rise of Property in Vancouver" (2011) 36 Law and Social Inquiry 694.

35 Personal Communication, 8 December 2015. 
There can be a significant mnemonic function in learning the law in context. Just as First Nations' oral traditions are reinforced by reference to physical objects and places,${ }^{36}$ common law legal traditions can be enhanced by attending to their physicality. ${ }^{37}$ When students learn in an embodied way, these lessons can be more deeply internalized ${ }^{38}$ These experiences are not lost when they return to the school. Contextualized lessons significantly reinforce what students have learned through more conventional casebook and classroom experiences.

A second set of examples regarding outdoor legal education is found at the University of Victoria [UVic] where I currently work. It occurs in our first year legal process class, which is held over two weeks at the beginning of each school year. Legal process is designed to provide newly arriving students with a "transactional overview" of legal studies in their broader context. Part of this course takes students to various locations throughout the city of Victoria. ${ }^{39}$ We teach outside to identify and discuss how the law shapes the world around us. In so doing, the faculty seeks to directly illustrate the impact of cases, contracts, statutes, customs, and other legal phenomena students will discuss in the classroom. To accomplish this objective, we organize all of the first-year students into five groups of twenty people, with two to three professors leading each group. As students walk between locations and meet with professors, they start to view their surroundings through a legal lens. At least five themes are explored in this experience: foundations of the city (Indigenous origins and the early settlement of Victoria); city environment (ecology, environmental, and real estate law); the international city (immigration, international trade, and tourism); the public/private city (municipal governance, development, and homelessness); and crime and punishment (public safety and social norms related to criminal and administrative law). ${ }^{40}$

A recent legal process experience demonstrates the importance of the multifaceted engagement between students, professors, and their outdoor surroundings:

36 Laurie Anne Whitt et al, "Belonging to Land: Indigenous Knowledge Systems and the Natural World" (2001) 26 Oklahoma City U L Rev 701.

37 For a discussion of issue, rule, application, and conclusion as mnemonic, see Peter Nash Swisher, "Teaching Legal Reasoning in Law School: The University of Richmond Experience" (1981) 74 Law Library Journal 534 at 539-542. Indigenous mnemonics are described in Horatio Hale, "Four Huron Wampum Records: A Study of Aboriginal American History and Mnemonic Symbols" (1897) 26 Journal of the Anthropological Institute of Great Britain and Ireland 221; Angela Haas, "Wampum as Hypertext: An American Indian Intellectual Tradition of Multimedia Theory and Practice" (2007) 19 Studies in American Indian Literatures 77.

38 Barbara Spellman \& Simone Schnall, "Embodied Rationality” (2009-2010) 35 Queen's LJ 117; Jennifer Nedelsky, "Embodied Diversity and the Challenges to Law" (1996-1997) 42 McGill LJ 91.

39 While many have contributed to this effort, Deborah Curran has been a prime architect of the field school aspects part of legal process.

40 While these visits are admittedly very brief, they form an important bridge for later law school experiences. Students learn more about law's complicated relationship with the world around them. They briefly see how treaties, land claims, and British colonialism and constitutionalism shapes the very streets they walk. They get a glimpse into how international trade facilitates the consumption of their favorite goods and services. They are introduced to the relationship between the relationship between environmental law and real estate development around the inner harbour. They see the physicality of the siting of certain forms of crime such as prostitution, gambling, or drug use, including how municipal bylaws control the use of sidewalks and work to confiscate of the belongings of people who are homeless and facilitate their same use for trade and commerce for the wealthier citizens and visitors. 
Our Trounce Alley spot went really well today ... The five groups were all very engaged ... We got them imagining what that spot was like in the late 19th century, and gave them the history of prostitution [in Victoria] through the stories of Thomas Trounce and Stella Carroll. We concluded by getting them to look down Trounce Alley and imagine whether it was still a place frequented by sex workers: whether the rooms that are visible from the street are modern day brothels. The questions were good, and they enabled, particularly Michelle [Lawrence], to draw some good connections between the space and other ways that social relations are produced by law, space and ideas of crime.

One interesting moment you might appreciate came at the first group. After we finished and had answered a few questions, one of the participants just to my left said: "What is this?" It took me a moment to realize she was not a student, but a member of the public who had joined our group and silently listened. I said: "this is law school!" which evoked some laughter. She then went on to thank us and to thank the students for their earnest and insightful questions. She was not only a student but also an escort, someone who would describe her work as therapy for people with disabilities. She was very moved by the conversation: its non-judgment and openness and how engaged the students were. I would imagine it was also quite a powerful moment for the students, as the young woman before them did not fit the media's stereotype of sex worker. You could not have created a better teaching moment, and you could not have scripted that kind of honesty. ${ }^{41}$

This experience illustrates the sometimes unexpected nature of learning that occurs when moving beyond the law school's walls. Flows of information are more unpredictable. Professors cannot control what happens to the same degree. The fluidity of their surroundings impacts a professor's teaching in direct and indirect ways. Since the physical context plays a more active role in student learning, professors must prepare in different ways to attend to their student's experiences. Likewise, students are also placed in a different role when their computers and books are nowhere to be seen. While these technologies will be used to prepare and debrief from outdoor educational experiences, students themselves draw on different skills when their participation is not mediated by writing and other textual cues. The development of mindfulness and other "in-the-moment" skills are important professional competencies. $^{42}$ They can be explicitly cultivated by teachers and students when outdoor legal educational experiences are effectively designed and implemented.

UVic also offers upper-year courses with strong outdoor components. Deborah Curran designed and has taught the field course in environmental law and sustainability on an intensive basis in the summer for the past five years. The course takes place at the Hakai Institute on Calvert Island on British Columbia's mid-coast. This island is approximately 480 kilometres from Victoria as the crow flies. Students live in a residential setting on a remote Pacific Ocean beach. Throughout the course, they engage deeply with this rich physical setting. They talk with local people and work with other professionals who study the area. In the process, students learn how lawyers are working with scientists, provincial authorities, First Nations communities, and energy industries to strengthen the local ecology and economy: "The purpose of this course is help students understand complex legal structures. They do

41 Gillian Calder, faculty email communication, 15 September 2015.

42 Leonard L Riskin, "The Contemplative Lawyer: On the Potential Contributions of Mindfulness Meditation to Law Students, Lawyers, and Their Clients" 7 (2002) Harv Negotiation L Rev 1. 
this by working with the law's intricacies in a specific place. In this case the geography of the Central Coast serves as their classroom. The course goals are framed as follows:

- Understanding some of the ecology, geography, history, and legal landscape of the Central Coast region of B.C;

- Applying the law of aboriginal rights and title in the context of the Central Coast and the communities of the Heiltsuk Nation, Kitasoo/Xai'xais Nation, Nuxalk Nation and Wuikinuxv Nation;

- Examining the use of science in law and the challenges of establishing standards for environmental quality, extraction of natural resources, and proof of environmental harm;

- Evaluating the land and marine use planning processes in the Central Coast and their results;

- Assessing the impact of national and provincial energy law and policy on remote communities and the environment;

- Developing writing, team work, facilitation and presentation skills; and

- Becoming familiar with a range of environmental law issues, actors, and strategies for using the legal system to pursue sustainability goals." 43

Regarding her experience with outsider legal education, Deborah Curran observes:

We learn differently when we change the physical context. To experience law in action in a place, and how that law manifests in the physical environment or how the physical environment shapes the law, creates opportunities for deep learning that listening to someone tell you about the law cannot provide. Engaging all of our senses when looking at zoning in an urban environment and what it does to a streetscape or handling kelp and talking with members of the Heiltsuk community when considering the impact of the Supreme Court of Canada's Gladstone case that acknowledged a commercial aboriginal right to herring roe-on-kelp cements the learning both mentally and physically. ${ }^{44}$

The work of Harris, Curran, and others like those who teach outdoors education at UVic stands among a broader tradition of outdoor education in a university context. Law schools should not "reinvent the wheel" when deploying this pedagogy. Much is known in other departments about how to effectively deliver these courses. The further development of outsider education should draw on these wider university insights, such as those gained in outward-bound education. Of course, these insights will be modified to advance law school objectives. However, the cross-pollination of ideas between departments

43 The Hakai Curse syllabus outlines the areas of study: "This course explores the structures of law and policy that shape environmental governance in the Central Coast of B.C. The goal is to apply legal and policy lenses to the topics of (1) aboriginal rights and title, (2) science in law, (3) land use and marine planning, and (4) the impact of energy systems in B.C. on remote communities to understand the overlapping jurisdictional and governance systems that shape the region" (on file with the author).

44 Deborah Curran, personal email communication, 5 December 2016. 
could be particularly fruitful. Multi-disciplinary insights should undergird any law school's attempts to further develop curricula in this regard..$^{45}$

\section{LEARNING FROM THE LAND: UNDERSTANDING INDIGENOUS PEDAGOGIES}

Outdoor legal education also provides significant room for developing pedagogies that are attentive to Indigenous legal traditions. ${ }^{46}$ It is critical to remember that these pedagogies will not be appropriate to all law school courses. Nevertheless, they can be an important part of a school's repertoire for increasing student insight and skills. Like a few grains of yeast in the preparation of bread, the addition of Indigenous law's methodologies may positively lift the entire institution. This article does not suggest that Indigenous law "take over" any law school's legal curriculum. I am only trying to put Indigenous law in its proper "place." While the intensity of engagement will vary, all law schools should consider ways in which they can teach Indigenous law, which after all is a vital part of the laws of Canada. ${ }^{47}$

Thus, in enhancing Indigenous education, each law school would do well to pay attention to the Indigenous Nations around them, even in urban settings. ${ }^{48}$ Students and faculty would find significantly greater opportunities for engagement if they respectfully developed courses and programming with practitioners, communities, and teachers who are Indigenous to the school's immediate physical setting. Learning about local Indigenous law will help students interact differently with their surrounding physical environments throughout their three-year enrolment. Even when a law school has a national student body or focuses on Indigenous law more generally, it is equally vital that local Indigenous legal insights be taught, studied, applied, critiqued, and experienced in direct, as well as more abstract, ways. This will reinforce the notion that law does not just flow from legislatures, courts, administrative bodies,

45 I have been particularly impressed by an initiative of the University of Calgary Business School in this light. David Lertzman of the Haskayne School of Business at the University of Calgary teaches a course entitled Rediscovering Leadership at the Barrier Lake Field Station in Kananaskis Alberta. Each summer since 2004, Lertzman has taken students into the Rocky Mountains outside of Calgary with the goal of cultivate core leadership skills for corporate responsibility in the context of sustainable development. The course allows business students to reflect on their surroundings in a direct way by engaging with Indigenous teachers, Elders, and outdoor leaders.

46 For a deep discussion about land-based pedagogy in one Indigenous context, see Keith Basso Wisdom Sits in Places: Landscape and Language among the Western Apache (Albuquerque, NM: University of New Mexico Press, 1996).

47 This point was canvassed in an earlier article. John Borrows, "Fourword: Issues, Individuals, Institutions and Ideas" (2002) 1 Indigenous LJ 1.

48 Various law schools have signalled relationships with Indigenous peoples in their halls. The Musqueam Declaration hangs in the Indigenous classroom in the Faculty of Law at the University of British Columbia Law; for its contents, see <http://www.musqueam.bc.ca/sites/default/files/musqueam_declaration.pdf>. Visitors to the law school are also welcomed by the Capilano house post, carved by Musqueam carver Brent Sparrow. See <http://aboriginal.ubc.ca/2012/04/14/new-musqueam-house-post-at-allard-hall/>. University of Victoria Law School has a Coast Salish Spindle Whorl and blanket in its entrance. See Patty Pitts, "Law Holds Ceremony," The Ring, <http://ring.uvic.ca/96oct18/nativelaw.html>. The University of Toronto displayed the Two-Row-Wampum in its main foyer before recent renovations. See Jean Teillet, "Recap: Jean Teillet," Nexus (2014),

<http://www.law.utoronto.ca/news/nexus/nexus-archives/nexus-springsummer-2014/recap-jean-teillet>. Osgoode Hall Law School also signals Indigenous relationships on its walls. See < http://www.osgoode.yorku.ca/aboriginal-artproject/>. For a discussion of Indigenous peoples and recognition in urban spaces, see Evelyn Peters, "Emerging Themes in Academic Research in Urban Aboriginal Identities in Canada, 1996-2010” (2011) 1 Aboriginal Policy Studies 78. 
or other positivistic processes. Law is also sourced in specific First Nations, Métis, and Inuit legal systems that give rise to obligations and rights in particular contexts.

Distinctive Indigenous legal methodologies can be further developed and applied to assist students in learning law on and from the land. ${ }^{49}$ There are many examples regarding Indigenous law being sourced in the land. ${ }^{50}$ When I speak of land, I am also speaking of all of the natural phenomenon associated with the land, such as water. ${ }^{51}$ One prominent declaration of land-based laws was evident during the Gitksan and Wet'suwet'en Hereditary Chiefs opening statement in Delgamuukw v British Columbia. ${ }^{52}$ As readers will recall, this case tested the existence of Aboriginal title in British Columbia. ${ }^{53}$ In outlining how law is sourced in the land, Chiefs Gisday Wa and Delgam Uukw said:

For us, the ownership of territory is a marriage of the Chief and the land. Each Chief has an ancestor who encountered and acknowledged the life of the land. From such encounters come power. The land, and plants, the animals and the people all have spirit, they all must be shown respect. That is the basis of our law.

The Chief is responsible for ensuring that all of the people in his House respect the spirit in the land and in all living beings. ... My power is carried in my House's histories, songs, dances and crests. It is recreated at the Feast when the histories are told, the songs and dances performed and the crests displayed. With the wealth that comes from the respectful use of the territory, the House feeds the name of the Chief in the feast hall. In this way, the law, the Chief, the territory, and the Feast become one. ... By following the law, the power flows from the land to the people through the Chief, by using the wealth of its territory. ${ }^{54}$

This statement demonstrates how Gitksan and Wet'suwet'en law flows from their relationship with the earth. ${ }^{55}$ The Delgamuukw case was built from this perspective. ${ }^{56}$ Outside the case, the Chiefs use the

49 Gregory Cajete, Look to the Mountain: An Ecology of Indigenous Education (Asheville, NC: Kivaki Press, 1994)

50 The leading book on this subject in the Australian context is CF Black, The Land Is the Source of the Law: A Dialogic Encounter with Indigenous Jurisprudence (New York: Routledge, 2011).

51 R Bedard, "Keepers of the Water: Nishnaabe-kwewag Speaking out for the Water" in LA Simpson, ed, Lighting the Eighth Fire: The Liberation, Resurgence, and Protection of Indigenous Nations (Winnipeg, MB: Arbeiter Ring Publishing, 2010) at 89-110.

52 For more information concerning the background of the Delgamuukw case, see Arthur Ray, "Native History on Trial: Confessions of an Expert Witness" (2003) 84 Canadian Historical Review 253 at 263; Robin Riddington, "Fieldwork in Courtroom 53: A Witness to Delgamuukw v. BC” (1992) 95 BC Studies 12.

53 Delgamuukw v British Columbia, [1997] 3 SCR 1010.

54 The Address of the Chiefs, 11 May 1987, in Don Monet \& Skanu'u (Ardthye Wilson), eds, Colonialism on Trial: Indigenous Law Rights and the Gitksan and Wet'suwet'en Sovereignty Case (Philadelphia, PA, and Gabriola Island, BC: New Society Publishers, 1992) at 22.

55 For further descriptions of this process, see Richard Overstall, "Encountering the Spirit in the Land: Property in a Kinship-Based Legal Order” in John McLaren, Andrew R Buck \& Nancy E Wright, eds, Despotic Dominion: Property Rights in British Settler Societies (Vancouver: UBC Press, 2004) at 22.

56 Antonio Mills, Eagle Down Is Our Law: Witsuwit'en Law, Feasts and Land Claims (Vancouver: UBC Press, 1994); Antonio Mills, Hang onto These Words: Johnny David's Delgamuukw Testimony (Toronto: University of Toronto Press, 2005). 
land as a legal resource for strengthening their house and its relationships. ${ }^{57}$ The histories, songs, crests, and food from the land are organized in particular ways. ${ }^{58}$ Totem poles are erected to encode these histories and crests, and they are purposely rooted in the earth to communicate a house's law. ${ }^{59}$ They are marshalled as authority for the house's past and future actions. ${ }^{60}$

Reading the earth, through poles, songs, clans, and histories is not unique to the Gitskan and Wet'sewet'en. Similar appeals to the earth, though culturally distinct to each group, can be found in most Indigenous legal traditions. ${ }^{61}$ The Cree talk about miyo-wicehtowin and witaskewin. ${ }^{62}$ The Blackfoot discuss the concepts of kakyosin and mokaksin. ${ }^{63}$ The Haudenosaunee relate their Great Law of Peace to pine trees, eagles, and other natural phenomena. ${ }^{64}$ The Mik'maq source Netukulmik. ${ }^{65}$ The Scewepmec value the natural-world sourcing of their laws: yiri7 re stsq'ey's kucw. ${ }^{66}$ The Hulquminum advance the idea of snuw'uyulth. ${ }^{67}$ The Haida apply Yah'gudaan. ${ }^{68}$

My own community, the Chippewas of the Nawash at Neyaashiinigmiing also regard the earth as an important legal resource. The Anisinaabe have a tradition of practicing law by reference to the natural

57 Richard Daly, Our Box Was Full: An Ethnography for the Delgamuukw Plaintiffs (Vancouver: UBC Press, 2005).

58 For a general description of these legal relationships, see, generally, Antonia Mills, Eagle Down Is Our Law: Witsuwit'en Law, Feasts, and Land Claims (Vancouver: UBC Press, 1994); Antonia Mills, "Hang onto These Words": Johnny David's Delgamuukw Testimony (Toronto: University of Toronto Press, 2005).

59 See Gisday Wa \& Delgam Uukw, The Spirit in the Land (Gabriola, BC: Reflections, 1989) at 26. The pole that encodes the history of the House through its display of crests, also recreates, by reaching upwards, the link with the spirit forces that give the people their power. At the same time, it is planted in the ground, where its roots spread out into the land, thereby linking man, spirit power, and the land so they form a living whole. Integral to this link and the maintenance of the partnership is adherence to the fundamental principles of respect for the land and for its life forms.

60 Richard Overstall, 'Encountering the Spirit in the Land: Property in a Kinship-Based Legal Order' in John McLaren, Andrew R Buck \& Nancy E Wright, eds, Despotic Dominion: Property Rights in British Settler Societies (Vancouver: UBC Press, 2004).

61 For general information about other Indigenous legal traditions that draw from the land and water, see Raymond Austin, Navajo Courts and Navajo Common Law: A Tradition of Tribal Self-Governance (Minneapolis: University of Minnesota Press, 2009); Justin Richland, Arguing with Tradition: The Language of Law in Hopi Tribal Court (Chicago: University of Chicago Press, 2008).

62 Harold Cardinal \& Walter Hildebrandt, Treaty Elders of Saskatchewan (Calgary: University of Calgary Press, 2000) at 14-20, 39-42.

63 Betty Bastien, Blackfoot Ways of Knowing (Calgary: University of Calgary Press, 2004) at 119-127.

64 William Fenton, The Great Law and the Longhouse: A Political History of the Iroquois Confederacy (Norman, OK: University of Oklahoma Press, 1998).

65 K Prosper et al, "Returning to Netukulimk: Mi'kmaq Cultural and Spiritual Connections with Resource Stewardship and Self-Governance" (2011) 2 International Indigenous Policy Journal, <http://ir.lib.uwo.ca/cgi/viewcontent.cgi?article=1037\&context=iipj>. For further context, see Sakej Henderson, "First Nations' Legal Inheritances: The Mikmaq Model” (1995) 23 Manitoba LJ 12; James [Sákéj] Youngblood Henderson, "Mikmaw Tenure in Atlantic Canada" (1995) 18 Dal LJ 196 at 218; Trudy Sable \& Bernie Francis, The Language of This Land, Mi'kma'ki (Sydney, NS: Cape Breton University Press, 2012).

66 For further discussion of these laws, see Ron Ignace, Our Oral Histories Are Our Iron Posts: Secwepemc Stories and Historical Consciousness (PhD dissertation, Simon Fraser University, 2008).

67 S Marlo Paige, "In the Voices of the Sul-hween/Elders, on the Snuw'uyulh Teachings of Respect: Their Greatest Concerns Regarding Snuw'uyulh Today in the Coast Salish Hul'q'umi'num' Treaty Group Territory" (MA thesis, University of Victoria, 2004) at 1.

68 Susanna Quail, “Yah'guudang: The Principle of Respect in the Haida Legal Tradition” (2014) 47 UBC L Rev 673. 
world. ${ }^{69}$ The Anishinaabe word for this concept is gikinawaabiwin. ${ }^{70}$ The word akinoomaage is also used to describe this phenomenon. It is formed from two roots: aki and noomaage. "Aki" means earth and "noomaage" means to point towards and take direction from. The idea this word conveys is that analogies can be drawn from our natural surroundings and applied to, or distinguished from, human activity. This is the heart of Anishinaabe legal reasoning: parallel situations are correlated, dissimilar situations are distinguished. ${ }^{71}$ In this legal approach, the environment becomes the legal archive that practitioners read and use to regulate their communities. ${ }^{72}$

In this legal tradition, the earth has a culture that the Anisinaabe strive to embed in their laws. These principles may often be found in the Anishinaabe language. For instance, there is a time in the early Ontario spring when cold and warm air masses intermingle, causing fine mists to rise over the earth. The word used to describe this phenomenon is aabawaa, which means warm and mild. At these moments, winter starts to loosen her grip on the land. The snows melt, and waters start to flow. Sap can begin running through the trees as nature prepares to nurture new life. Interestingly, the Anishinaabe word for forgiveness is related to this moment in time; the word for forgiveness is aabawaawendam. Thus, forgiveness can be analogized to loosening one's thoughts towards others; to letting relationships flow more easily, with fewer restrictions. Forgiveness is a state of being warmer and milder towards another; it signifies a warming trend in a relationship. Notice that forgiveness, like the clearing of early spring mists, does not occur in an instant. Warmth needs to be applied through a sustained period of time for mists to clear. Clarity of vision takes a while to develop as spring mists do not dissipate immediately; time is often needed to "clear the air" and bring fairer views. So it is with forgiveness.

This example provides a glimpse into understanding how reasoning about, and practicing, law can be related to "reading the land." 73 Chief Gary Potts, of the Temagami Anishinaabe, exemplified

69 M Greenwood \& S de Leeuw, "Teachings from the Land: Indigenous People, Our Health, Our Land, and Our Children" (2007) 30 Canadian Journal of Native Education 48.

70 Anishinaabe language professor and linguistic Brenda Fairbanks (personal correspondence, 17 January 2014) traced the etymology of gikinoo'amaage as follows:

- "Gikinaw" - learn, know, recognize

- "i" - by instrument

- "amaw" - applicative

- "ge" - detransitive (to general people).

71 For a more general discussion of analogical reasoning, see Cass R Sunstein, "On Analogical Reasoning," Commentary (1993) 106 Harv L Rev 741; for a discussion of the cultural context of analogical reasoning, see Roberto Unger, "The Critical Legal Studies Movement" (1983) 96 Harv L Rev 561 at 570; for a discussion of the embodied nature of analogical reasoning, see George Lakoff \& Mark Johnson, Philosophy in the Flesh: The Embodied Mind and Its Challenge to Western Thought (New York: Basic Books, 1999).

72 For a discussion of how rocks can be read and marked, see Ron Morton \& Carl Cawboy, Talking Rocks: Geology and 10,000 Years of Native American Tradition in the Lake Superior Region (Minneapolis, MN: University of Minnesota Press, 2000); Grace Rajnovich, Reading Rock Art: Interpreting the Indian Rock Paintings of the Canadian Shield (Toronto: Natural Heritage/Natural History, 1994). For a discussion of how animals can be read, see Heidi Bohaker, "Reading Anishinaabe Identities: Meaning and Metaphor in Nindoodem Pictographs" (2010) 57 Ethnohistory 11; Michaeil Pomedli, Living with Animals: Ojibwe Spirit Powers (Toronto: University of Toronto Press, 2014).

73 In some cases, the demands of the land and the need to share it are read and woven into treaty agreements. Victor Lytwyn, "A Dish with One Spoon: The Shared Hunting Grounds Agreement in the Great Lakes and St Lawrence Valley" in David Pentland, ed, Papers of the Twenty-Eighth Algonquian Conference (Winnipeg: University of Manitoba, 1997) 210. 
Anishinaabe legal reasoning related to the land through an experience he shared from his territory. ${ }^{74} \mathrm{He}$ wrote:

I remember once coming across an old white pine that had fallen in the forest. In its decayed roots a young birch and a young black spruce were growing, healthy and strong. The pine tree was returning to the earth, and two totally different species were growing out of the common earth that was forming. And none was offended in the least by the presence of the others because their own identities were intact.

When you walk in a forest you see many forms of life, all living together. They each have their own integrity and the capability to be different and proud. I believe there is a future for native and non-native people to work together because of the fundamental fact that we share the same future with the land we live on.

We will never be able ... to build another planet like earth or build a covered bridge to another planet and start all over again. We need to acknowledge that the land is the boss. $^{75}$

Chief Potts' attempt to describe what he saw in the bush and draw meaning from his experience is an example of gikiniwaabiwin and akinoomaagewin. This is an example of physical philosophy, which is aimed at drawing law from real-world experiences.

In addition to direct observation of the land, stories related to the land also play an important role in transmitting legal knowledge. ${ }^{76}$ Basil Johnson, an Elder from my community who passed away while this article was being written, often talked about how Anishinaabe law is learned by studying the earth. ${ }^{77}$ He often told stories about insects, birds, and animals to illustrate the rights and obligations of our Band Council, Chiefs, and general community members. ${ }^{78} \mathrm{He}$ tried to impress on me that, as a law teacher, I needed to study the earth and learn her stories to find principles that could be applied to more effectively regulate our behaviour. ${ }^{79}$ As I searched his writings, I came across a quote in a related vein wherein he wrote:

74 This paragraph is quoted from John Borrows, Freedom and Indigenous Constitutionalism (Toronto University of Toronto Press, 2015). This quote is a central part of Aaron Mills' theoretical framework, and I am grateful for him reacquainting me with it.

75 Gary Potts, "Growing Together from the Earth" in Diane Engelstad \& John Bird, eds, Nation to Nation: Aboriginal Sovereignty and the Future of Canada (Toronto: Anasi Press, 1992) 199.

76 For further development of this point, see Margret Noodin, "Megwa Baabaamiiaayaayaang Dibaajomoyaang: Anishinaabe Literature as Memory in Motion" in James Howard Cox, James H Cox \& Daniel Heath Justice, eds, The Oxford Handbook of Indigenous American Literature (Oxford: Oxford University Press, 2014) 175.

77 A sample of Dr Johnston's work can be found in Basil Johnston, The Manitous: The Spiritual World of the Ojibway (Toronto: Key Porter Books, 2002) at 17-50; Basil Johnston, Ojibway Ceremonies (Toronto: McClelland and Stewart, 1982) at 165-166; Basil Johnston, Ojibway Heritage (Toronto: McClelland and Stewart, 1976) at 151-153.

78 Basil Johnston, The Bear Walker and Other Stories (Toronto: Royal Ontario Museum, 1995).

79 Basil Johnston, Living in Harmony: Mino-nawae-indawaewin (Cape Croker, ON: Kegedonce Press, 2012): "In our ancestor's ancient society there was only one abiding principle that governed all of life, of whatever species; plants, insects, birds, animals, fish and humans, and that was 'live in harmony.' ... There were no other laws or commandments 
Learning comes not only from books but from the earth and our surroundings as well. Indeed, learning from the mountains, valleys, forest and meadows anteceded book knowledge. What our people know about life and living, good and evil, laws and the purposes of insects, birds, animals and fish comes from the earth, the weather, the seasons, the plants and the other beings. The earth is our book; the days its pages; the seasons, paragraphs; the years, chapters. The earth is a book, alive with events that occur over and over for our benefit. Mother earth has formed our beliefs, attitudes, insights, outlooks, values and institutions. ${ }^{80}$

Learning from the earth in this way takes time. ${ }^{81}$ The idea that laws (among other human activities) can be learned from reading the earth requires practice. It requires a literacy that is not often taught and developed in a university setting. ${ }^{82}$ Developing such land-based literacy should be adopted as a more explicit goal within Canadian law schools.

\section{MY EXPERIENCE: ANISHINAABE LEGAL EDUCATION}

One way in which students are being slowly introduced to Indigenous land-based laws is through spending short periods of time on the land with Indigenous legal practitioners. For example, in 2014, students of the Bora Laskin Faculty of Law at Lakehead University were invited to the Fort William First Nation in Thunder Bay, Ontario. They met Damien Lee and Jacob McKay, who are revitalizing Anishinaabe law within their First Nation through the redevelopment of their local sugar bush. Tapping maples trees and boiling down their sap has long been a traditional activity of the Anishinaabe, but there are also many important principles, values, and processes related to this activity that have application beyond the sugar bush itself. ${ }^{83}$ Damien is currently a doctoral candidate and university teacher who was adopted into, and grew up in, the Nation; Jacob recently completed his Bachelor of Arts honour's degree and recently moved back to Fort William. Both are working within their community to reintroduce the practice of sugaring in exciting ways.

Damien extended an invitation to myself and Lakehead law professor Karen Drake to visit the site with her first-year Indigenous legal traditions students. The bush is nestled in a canyon at Animikii Waajiw (called Mount McKay in English). The sides and top of the mountain are regarded as

except 'mino-nawaendaudik' or 'mino-nawaemaudik' or 'weekauneandik.' Be of good kinship or respect one another as ought next of kin or be of good will."

80 Basil Johnston, Honour Earth Mother: Mino-Adujaudauh Mizzu-Kumik-Quae (Cape Croker, ON: Kegedonce Press, 2003) at $\mathrm{v}$.

81 The role of time in learning is one reason Elders are often Indigenous peoples' greatest law keepers. See Michael McNally, Honoring Elders: Aging, Authority, and Ojibwe Religion (New York: Columbia University Press, 2009).

82 For an explanation of how Indigenous literacy might be better developed, see Herman Michell, Working with Elders and Indigenous Knowledge Systems: A Reader and Guide for Places of Higher Learning (Vernon, BC: Charlton Publishing, 2014).

83 This research is currently being compiled as a doctoral dissertation at Trent University by Waaseyaa'sin Christine Sy, and it is called "Ishkigamiziganing (At the Sugarbush): Reclaiming Anishinaabeg Women's Economy for Maadjiimaadiziwin, Moving Life Forward." 
thunderbird nesting spots and thus are considered sacred by many Anishinaabe people across northern Ontario and even northern Minnesota. ${ }^{84}$ While we were on the land, the surrounding egg-shaped rocks and other land forms reminded us of these teachings. We also heard about the community's efforts to discuss and revitalize their citizenship laws by drawing analogies from their work at the sugar bush (ishkigamiziganing). For example, Damien and Jacob discussed their views on how the sugar bush creates the conditions for the community, the mountain, and individuals to (re)claim each other. They noted that, in order to make maple syrup for their community, individuals must take the responsibility for the annual sugaring activities. This, they shared, enfolds principles of Anishinaabe citizenship law; one's choice to either take care of, or neglect, their relations either strengthens or weakens, respectively, one's sense of belonging with the Anishinaabe nation and the degree to which the nation claims them back. ${ }^{85}$ Further, just as each sugaring season creates the opportunity for renewing these responsibilities, Anishinaabe citizenship also rests on renewing one's relationships in ways that centre mutual accountability and an obligation to care for others. Day-long experiences learning from Anishinaabe practitioners like Damien have found a place in select law schools over the years, although they remain largely ad hoc at present.

At the same time, there is a more sustained phenomenon developing in a few law schools that places law students in Indigenous communities for intensive four-day experiences. The Faculty of Law at UVic has been doing this for over twenty years. Called AbCamp, it was initiated in 1995 by student Ann Roberts: "While she was an undergraduate student at the University of Calgary, Roberts had heard of a similar camp held by the Peigan and Siksika people of the Blackfoot Nation for the RCMP." 86 With the help of First Nations RCMP officer and fellow student, Chris Pallan, and through the support of Dean David Cohen, the law school developed a program of financial support for the experience, through the Law Foundation and local law firms. The camp is organized by the students with the support of a faculty director and takes place each year in conjunction with local First Nations. ${ }^{87}$

During their time in these communities, the students participate in ocean canoe voyages, pit cooking, singing, drumming, storytelling, games of lahal, cedar bark weaving, hiking, and other traditional activities. ${ }^{88}$ During its first few years, the AbCamp experience was an opportunity to break down barriers between law students and local communities. In recent years, now that relationships are more fully formed, ideas and practices related to Indigenous law are implicitly and explicitly woven into the four-day gathering. Alumni continually report that it is one of the best experiences they have during law school. For instance, lawyer Claire Truesdale wrote:

84 For a discussion of Anishinaabe place names, see Basil Johnston, By Canoe and Moccasin: Some Native Place Names of the Great Lakes (Lakefield, ON: Waapoone Publishing, 1986).

85 Damien Lee is currently considering what Anishinaabe citizeneship practices can learn through narratives of Anishinaabe customary adoption as it is practised in his community. Damien Lee, "Adoption Is (Not) A Dirty Word: Towards An Adoption-Centric Theory Of Citizenship" (2015) 10 First Peoples Child and Family Review, <http://journals.sfu.ca/fpcfr/index.php/FPCFR/article/view/242/234>.

86 "AbCamp: Twenty Years of Understanding," <http://www.uvic.ca/law/home/news/current/AbCamp20thAnniversary.php>.

87 Nuu-Chah-Nuulth lawyer Karla Point has undertaken this responsibility over the past few years.

88 One former student's reflections on AbCamp (Chad Day of the Tahltan Nation) are recorded at <https://www.youtube.com/watch?v=P6B8ViCDYLI $>$. 
As a UVic alum, I attended the program myself. It is an introduction for new UVic law students to the cultures of the peoples in whose traditional territories they will be living and studying colonial law. But more than that, it is an eye opening and unsettling opportunity to learn about the modern reality of Vancouver Island First Nations. It is, perhaps most importantly, the barest of introductions to the legal traditions of the Island's indigenous peoples. It is a rare occasion for indigenous and non-indigenous peoples to come together in an atmosphere of respect and willingness to learn. The elders who addressed the students and guests on Saturday night spoke of the need to be able to look each other in the eye, talk to each other and respect one another. Only then, they said, can we begin to move towards healing the rifts between our communities. ${ }^{89}$

In a similar vein, UVic alum and lawyer Berry Hykin wrote:

AbCamp gives you a rare opportunity at the beginning of your legal education to have a hands-on experience and obtain a different perspective on law and its practical aspect ... It challenges you to see how the law actually affects people in real and profound ways. You carry that perspective with you all the way through law school so it can inform how you approach your studies and how you eventually approach your practice. The impact of First Nations, historically and currently, on our society is so profound. Especially for people going into the legal profession, I think it's extremely important that this vital part of our community is made tangible through the participatory experience of something like AbCamp. ${ }^{90}$

In recent years, students from UBC were invited to attend UVic's camp to allow them to enjoy the experience between schools and to work on ways to develop their own program. As a result, UBC has just completed its own second annual Indigenous law camp. ${ }^{91}$ Likewise, Osgoode Hall Law School has also completed its second annual Anishinaabe Law Camp, and I will now address this experience.

\section{A. Anishinaabe Law Camp: Working with Groups}

The Anishinaabe Law Camp, which is part of Osgoode Hall Law School, is hosted by the Chippewas of the Nawash First Nation at Neyaashiinigmiing on the shores of the Saugeen Peninsula in Ontario. This camp is partially organized by myself and my daughter Lindsay, who is a law student at UVic. My family on the reserve have also played a large role in its development and implementation. The program was initiated by Andrée Boiselle, who had been a student in the Faculty of Law at UVic. ${ }^{92}$ She had participated in UVic's Aboriginal Camp while working towards her doctoral degree in Victoria. She had

89 Claire Truesdale, UVic Law's AbCamp Celebrates Its 20th Anniversary at <http://www.jfklaw.ca/uvic-laws-abcampcelebrates-its-20th-anniversary/>.

90 "AbCamp," supra note 86.

91 A description of UBC law school's camp can be found at $<$ http://www.allard.ubc.ca/indigenous-legal-studiesprogram/indigenous-awareness-camp>.

92 A sample of Boiselle's work can be found in Andrée Boisselle, "Beyond Consent and Disagreement: Why Law's Authority Is Not Just about Will" in Jeremy Webber \& Colin Macleod, eds, Between Consenting Peoples: Political Community and the Meaning of Consent (Vancouver: UBC Press, 2010) 207. 
also participated with UVic professor John Lutz and University of Saskatchewan professor Keith Carlson in their Sto:lo Field School while she attended UVic. ${ }^{93}$ This field school took place in the Fraser Valley and was hosted by Sonny McHalsie and others within the Sto:lo community whom I wrote about previously. Andrée used this experience as a springboard for her doctoral field work with the Sto:lo Nation. When she started teaching at Osgoode Hall Law School, she found herself searching for ways to develop similar opportunities for students in central Canada. Thus, Andrée approached me and my family with a request that we consider ways in which we might introduce Osgoode Hall law students to Anishinaabe law. I had earlier shared my desire to do something like this one day. Thus, when she visited us, we enthusiastically received her idea and worked with her to bring it to fruition.

Andrée worked with her colleagues at Osgoode Hall Law School to develop support within the school and student body for the idea. She worked with her dean, Lorne Sossin, to develop an application for funding the event. Dean Sossin was very encouraging of the group, and he helped the school secure the necessary funds to initiate the camp. Expenses for the Camp primarily involved transportation, food, rental costs for facilities on the reserve, and honoraria for the Elders, other Anishinaabe law teachers, and the local administrator of the course. During the first camp, my sister Jennifer, who has a doctoral degree in family therapy, organized the administrative details from the reserve side. ${ }^{94}$

We identified the purpose of the camp as being to facilitate student understanding of Anishinaabe law by teaching and learning about how to regulate our behaviour and resolve disputes. The curriculum was organized to do this through introducing students to different sources of law at Neyaashiinigmiing. These sources included sacred, environmental, deliberative, positivistic, and customary sources. We also wanted to ensure that students experienced and applied law and moved beyond merely having it explained to them. It is this immersion experience in the context of a particular ecology and community that cannot be replicated in the classroom.

As noted, the first year the course was taught by Lindsay and myself. Resource people and teachers throughout the camp included Elders, band councillors, firekeepers, professors, lawyers, family members, and community members. In the second and third years, two additional teachers were added: Heidi Stark who teaches law and political science at UVic and Hannah Askew, a family friend and practitioner of Indigenous law at West Coast Environmental Law Association. Each year, approximately fifty Osgoode Hall law students and professors attended the camp. A number of select alumni, visiting professors, and friends have also attended the events. Furthermore, community support has also been strong as people have pitched in, dropped in to listen, or offered behind-the-scenes support.

The formal curriculum had the students participate in activities related to air, fire, water, earth, plants, animals, and fish. Each activity took place at a different venue to allow students to learn about the laws that flowed from each of these entities. Stories, songs, lectures, demonstrations, and hands on activities were used in various ways. We gathered by lakeshores, huddled together around fires, walked through dense hardwood forest, paddled across waters, and sprawled across our powwow grounds and in our

93 These camps are described in Keith Thor Carlson, John S Lutz \& David Schaepe. "Turning the Page: Ethnohistory from a New Generation" (2009) 2 University of the Fraser Valley Research Review 1.

94 Jennifer's academic work can be found at Jennifer Borrows, "Generative Fathering among the Canadian Chippewa: Narrative Accounts of the Circle of Life" (MSc thesis, Brigham Young University, August 1996) [unpublished]; Jennifer Borrows, "The Chippewa Experience with the Therapy Process: Stepping Stones to Healing" (PhD dissertation, School of Family Studies and Human Ecology, Kansas State University) [unpublished]. 
community centres. Students experienced pipe ceremonies, prepared medicine bundles, case briefed Anishinaabe stories, and handled treaty wampum. They were the beneficiaries of unplanned appearances by local community members. One time, they heard about the intense racism sometimes experienced by community members in seeking employment in surrounding towns. Another time, they received a lecture from a gifted orator related to our ethno-geological knowledge of the peninsula.

Students also ate from the bounty of the land. In addition to more conventional fare, they enjoyed whitefish, wild rice, moose, squash, beans, corn, and other local foods. They also learned first hand about the environmental challenges concerning clean, safe drinking water on the reserve. Neyaashiinigmiing is in a near pristine aquatic environment, yet boil water advisories were in place the first year and had just ended the second year. It may have surprised a few students to realize that only three short hours from Toronto, in a stunning physically clean setting, a community would face such challenges in securing basic necessities of life. Scepticism and critique about Anishinaabe and Canadian law intermingled with more positive messages about each system.

The first year we specifically involved a group of Elders in planning the camp and giving us guidance. We received excellent advice from Archie Johnston, Isabel Millette, Carlene Elliot, Jean Borrows, Norma Borrows, Basil Johnston, Tony Chegano, and Ross Johnston, among others. Elder Isabel Millette was given tobacco in accordance with our legal processes in connection with selecting a name for the camp. She consulted with Elders on the Language Committee at Cape Croker in identifying an ongoing theme for the camp. The name for the program that they selected is Anishinaabe Naakinagewin Gabeshiwin. Through study and further offerings, she also received a motto for the camp, which is "Pii dash Shkakimi-kwe giigidid aabdeg gbizindawaamin" ("When the earth speaks we will listen"). It was so beautiful that they chose this theme.

In reflecting on my experience of the first camp, I wrote the following to my friend and West Coast Environmental Law Association lawyer, Hannah Askew:

This camp was a dream come true, literally and figuratively. I made many good friends. ... I could also see how Anishinaabe law could be taught to others. Our own lawyers would benefit from something like this. They need to know our law when they represent us. I could also see how community members could have this experience, if they wanted it. I also thought about how interested friends and neighbours of the penninsula could go to a 4 day "Anishinaabe Law School" if we had the facilities. Other law schools like U of $\mathrm{T}$ could be invited on another September weekend. I can also see how an entire semester could be taught this way. Anyway, I have lots of thoughts running though my head for future potentialities. But if nothing ever happens along these lines, my joy is full. I will be forever happy and grateful for this moment. It was its own moment and I learned so much.

The three Osgoode Hall Anishinaabe Law Camps in which I have participated have been among the highlights of my career. Similar opportunities have been offered to law students at the University of Toronto law school in the form of an intensive course in Anishinaabe law. The course was entitled Indigenous law in context (LAW710H1F), and this class included an assignment in the form of a fact pattern assignment where Anishinaabe law had to be applied to identify legal issues and answer legal 
questions. In addition, an Anishinaabe law camp was recently offered to faculty and staff from the University of Windsor law school on the Walpole Island First Nation. This is the home community of Valerie Waboose, and she took care of the local arrangements with members of her community and the support of the law school, while Hannah Askew, Heidi Stark, and myself taught about Anishinaabe law, along with Elder Shirley Williams and Isabel Ozawamik from Trent University.

Students have reacted very positively to these experiences, and they were described in Obiter Dicta, Osgoode Hall's newspaper. ${ }^{95}$ Faculty also positively shared their thoughts concerning the program with Dean Lorne Sossin. Amar Bhatia, Ruth Buchanan, Shin Imai, Kent McNeil, Signa Daum Shanks, and Dayna Scott, along with Patricia Hennessy, who was the visiting judge-in-residence wrote:

We are the Osgoode professors who participated in the Anishinaabe Law Camp that Professor Andrée Boisselle organized and led earlier this month. We are writing this informal report to provide you with our feedback on this event and on Professor Boisselle's leadership. In our opinion, Andrée has made a major service and teaching contribution to the law school and the larger York community by designing and implementing this initiative. Andrée conceived this educational experience because Osgoode students, while receiving excellent grounding in Canada's common law system, have little or no exposure to the Indigenous legal orders that pre-dated the creation of Canada and continue to govern Indigenous communities. She thought the best way to make a modest start in this direction would be to bring a group of students and faculty to a local Indigenous community for three or four consecutive days to meet and learn from its teachers, practitioners, and elders. Further, she appropriately articulated the goals of the Camp to include not just exposing the participants to Indigenous intellectual

95 Serena Dykstra, Zachary Donofrio \& Jasleen Johal, Obiter Dicta (29 September 2014), <http://obiterdicta.ca/2014/09/29/anishinaabe-law-camp/>; Allison Grandish, "The Stories behind the Law: Anishinaabe Law Camp 2015," Obiter Dicta (13 October 2015), <http://obiter-dicta.ca/2015/10/13/anishinaabe-law-camp-2015/>: “The purpose of the camp was to provide an opportunity for students to learn on the land, engage with Anishinaabe legal traditions, and be introduced to Anishinaabe research methodologies. Rather than learning in a classroom through lectures, we participated in community-based teaching. Our instructors shared their experiences of learning Indigenous law and, to illustrate their journey, led us through a group activity in which we collaborated to address a legal issue through the approach used in Anishinaabe legal pedagogy - taking a story and interpreting it to determine what legal principles it proposed. Throughout the weekend, discussions of the protocols involved in components of the camp revealed the extent to which Indigenous traditions were woven into facets of the trip that I myself may have taken for granted. The most marked example was the procedures involved in observing the sacred fire and respecting the traditions that go into building and maintaining it. We also had the opportunity to converse with local and guest teachers during meals and our spare time, allowing students to discuss particular areas of personal interest related to Indigenous law. Elders and community members welcomed us into an exploration of Indigenous legal traditions and pedagogy by sharing their own stories, which both deepened our understanding of the material and illuminated the significance of what we were learning. ... Being welcomed into the space imbued us with a humbling sense of both gratefulness and responsibility. I can't speak for my fellow attendees, but I feel that the dedication and passion of our hosts inspired us to treat the learning experience as a starting point. Before leaving we sat around the sacred fire as it burned to embers, sharing our reflections. The common theme, beyond how grateful we were to be part of the experience, was a shared desire to learn more about the intersections between Indigenous law and what we hope to practice, to be conscientious about how our approach to practice may serve to unite communities or reinforce systemic oppression, and to remain committed to the values that drove us to law to begin with." 
resources, pedagogies, and modes of reasoning, but also "laying the ground," experientially and relationally, for the participants' further engagement with Indigenous political and legal traditions. In Andrée's analysis, this is like "planting a seed," so that the activities undertaken at the Camp would inform the participants' approach to crosscultural legal conversations and to the ongoing work of decolonization. She envisioned it as giving shape to their responsibility as legal scholars and practitioners to learn about and take account of Indigenous laws and perspectives.

The idea of teaching and learning law "on the land" is a significant contribution that Andrée brought to life at Osgoode in her own richly respectful and deeply thoughtful and responsible way. Her vision is that the camp, over time, will enhance the collective sense that our law school is "not only a space where a community of sophisticated legal thinkers committed to social justice gathers to learn, but it is actually rooted in place: in a particular history, territory, and in a set of longstanding relationships with normative implications" (Harry Arthurs Grant Application, 2014).

In practice, once on the land, the participants in the camp embraced these teachings. The program was carefully laid out so as to give students the opportunity to hear stories rooted in particular places, experiences, and relations, and these stories drew their strength from the land and water in whose company they were shared. The impact of the stories on the students was visibly obvious and was reflected in the sharing circle held at the end of the Camp. Many times, we heard someone refer to a particular story by referencing where the storyteller was at the time the story was told, and this is further evidence of the critical importance and pedagogical value of doing this type of experiential teaching on the land.

The warmth and generosity of the Neyaashiinigmiing community contributed enormously to the resounding success of the camp. We had the immense good fortune of being welcomed into the community by John Borrows ... and his daughter Lindsay. John and Lindsay took care of many of the local arrangements, especially the teachings: in addition to leading the pedagogical sessions and sharing their deep knowledge of Anishinaabe legal traditions with us, they arranged for elders and community leaders to instruct us on various aspects of Anishinaabe law and inform us of some of the current legal and political issues being faced by the community. John's mother Jean and Sister Jennifer also assisted in countless ways, generously sharing their time, knowledge, and warmth of spirit with us.

The benefits to students and faculty alike who attended the Camp cannot be easily summarized. As witnessed at the sharing circle, the diversity of lessons, teachings, and emotions experienced by participants was broad and deep. People shared jokes, songs, tears, and stories with one another in a heartfelt and genuine manner. Students and faculty spoke of the people they had met and learned from, such as the firekeepers, elders, and Borrows family teachers, including John and Lindsay. They spoke of the lessons they would take back, both personally and professionally, as well as a commitment to continue the work that had been started and to share their experiences with other students and their families. Looking at the limestone escarpments, seeing the replica wampum belts, and 
hearing of pre-colonial and post-Confederation treaties left an indelible impression of the maturity of the relationships that we had all stepped into in different ways as citizens, immigrants, and visitors to these lands and waters. It is fair to say that this impression was met with a sense of responsibility too, by student and faculty participants alike. While there has been a recent flourishing of scholarship around Indigenous laws and legal traditions, it's clear that much work remains to be done for our textbooks, course materials, students and faculty to reflect the knowledge and importance of Indigenous laws as sources of authority relevant to everyone. ...

We as faculty are grateful to have had the immense privilege of being welcomed into an Indigenous community and taught by learned experts and practitioners of one of Canada's many Indigenous legal traditions. We learned a great deal from this experience that will inform both our scholarship and our teaching, and hope that we may be able to help the community in return with the many challenges they face in dealing with the Canadian legal system. It is also our hope that other Osgoode faculty will be able to have the same kind of experience in years to come. We are convinced as well that the students who took part will bring what they have learned back to their fellow students at Osgoode and to their practice of law when they graduate.

This Camp has created a link with an Indigenous community that we hope will continue to flourish. We all know that Indigenous legal traditions have not been accorded the respect they deserve in Canada. Our willingness to go to an Indigenous community and learn about its legal traditions with open minds and hearts sends a vital message: we acknowledge the importance of Indigenous legal traditions as essential parts of Canada's legal landscape and want to be part of the change that will accord them the respect they deserve in Canadian legal circles and society more generally. ${ }^{96}$

\section{B. Guided Sole Practitioner Experiences: Working with Individuals}

In addition to facilitating group-based legal educational experiences, there is also room for taking individual students into communities and learning law from experienced Indigenous practitioners. I have seen this occur most strongly with graduate students, though doctoral law students have also benefitted from these interactions on a more ad hoc basis. Some of the graduate students I have supervised who have worked with Indigenous legal traditions include, among others, Kinwa Bluesky, Harold Cardinal, Robert Clifford, Aimee Craft, Hadley Friedland, Dawnis Kennedy, Danika Littlechild, Johnny Mack, Maxine Matilpi, Aaron Mills, Nancy Sandy, Perry Shawana, Kerry Sloan, and Jacinta Ruru. Most of these people worked on the land with Indigenous legal practitioners at some point during their dissertation studies. Each of them explains in rich detail their methodologies in working with Indigenous ideas and practitioners outside of the law school's walls.

For example, Sarah Morales worked closely with Hul'qumi'num law keepers on Vancouver Island during the half-dozen years of her graduate work. She often ventured into the six Salish communities with whom she worked with to be immersed in Hul'qumi'num laws and the Hul'qumi'num legal tradition. By following Hul'qumi'num legal process learned under the guidance of experienced

96 On file with author. 
practitioners Sarah discovered how legal principles were embedded in the land and reinforced with stories. ${ }^{97}$ In describing this process, she writes:

Through the land you can know who my community is and the shape of our legal traditions. Land is the very entity that has inspired, recorded and preserved our histories. ...Through my educational journey, I have learned that "places possess a marked capacity for triggering acts of self-reflection, inspiring thoughts about who one presently is, or memories of who one used to be, or musings on who one might become." Different landscapes conjure different emotions. My territory prompts reflection upon what was "experienced" or "learned" in those places. As I spent my days pouring over books, learning about the history of my community and listening to stories about Our First Ancestors, I found my source of strength - the land. I began to picture my traditional territory in a different way. ... Our laws were written in the lands - quietly and majestically surrounding us, waiting for their renewal. These are the laws that can bring healing and health to my people. As a result, when I now return home to my community I don't focus on the over-development of our territory and the poverty of our reserve lands. Instead I look up towards Swuq'us; I see the face of my First Ancestor Stutson and remember the teachings he gave me. This realization is what I hope to share with my community through this dissertation. I want to change how they envision our landscape. I want them to draw strength from the laws embedded in the lands. I want them to recognize that we are a strong people. I want them to see we have a living legal tradition that operates within our communities and guides our daily decision-making processes. ${ }^{98}$

Morales' dissertation chronicles what she learned from the land and her Hul'qumi'num teachers as she studied and practised law beyond formal courts, classrooms, and legislative bodies.

Danika Littlechild also had a similar experience of learning from the land through drawing on Cree legal traditions during her Master's of Law experience. Danika practises law on the Ermineskin First Nation, which is her home. She is also vice-president of the Canadian Commission for the UN Educational, Scientific and Cultural Organization and has done significant work throughout her life on Cree and Blackfoot water law. Her thesis describes how "the recognition of Indigenous legal traditions

97 Some of Sarah's main "law professors" within this tradition included Arvid Charlie (Luschiim), Roy Edwards (Si'emtuletsu), Florence James (Thiyaas), Wes Modeste (Qwustenuxun), Robert Morales (Tl'ul' thut, and her Father), Joe Norris, Willie Seymour (Qwulthutstun), Angus Smith (Shhwuw wul't'hw and her Great Uncle). Sarah also had opportunities to mingle with, and learn from, other respected Elders in her work, including Joey Caro (Sii'meylutun), Wayne Charlie (Pul xulstse), John Elliott, (Chief of Stz'uminus, Chemainus First Nation). Roger Elliot, Chad Harris (Qwustenuxun), George Harris (Hwulqeletse'), Ray Harris (Shulqwilum), Sylvia Harris (Qutsumaat), Martina Joe (Sulsulmunaat), Tim Kulchyski, Tim (Q'utxu-lenuhw), Frank Norris (Yustelets'e), August Sylvester (Thy-xey iem), Laura Sylvester (Quay al si aht), Rich Thomas, (Puhuluqtun). Sarah Morales, "Stl'ul Nup: Legal Landscapes Of The Hul'qumi'num Mustimuhw" (Windsor Yearbook of Access to Justice, Forthcoming in this special issue) at 103.

98 Sarah Morales, "Snuw'uyulh: Fostering an Understandingo of the Hul'qumi'num Legal Tradition" (PhD dissertation, University of Victoria, 30 April 2015) at 41-42, <https://dspace.library.uvic.ca:8443/bitstream/handle/1828/6106/Morales_Sarah_PhD_2015.pdf?sequence=6\&isAllowed=y $>$ Appendix A and B. 
has a transformative capacity to secure better water management and governance." 99 She discusses how Cree law is central to creating better relationships with water both within her community and with the wider Canadian state. Danika describes the laws she learned in regard to water throughout her thesis, and she uses this information to work towards reconciliation with municipal, provincial, and federal governments. In taking this course, she regards Cree law as a vital element of this reconciliation. In this light, Danika's thesis is rooted in Cree "laws [that] have developed as a result of observations of the

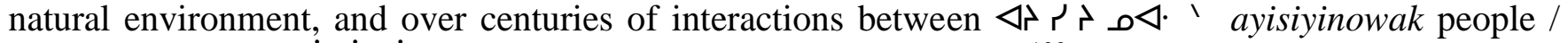
human beings and $\triangleright \dot{b} \dot{\Delta} \cdot \dot{L} \triangleleft \cdot \cap P+$ okâwîmâwaskiy mother earth." 100 Thus, she writes:

$\sigma \wedge+$ Nipiy is the Cree word for water. $\sigma$ ל "Ni" derives from niya, meaning "I" or "I am." $\Lambda \mathrm{L} \cap \Delta \cdot \Delta^{\prime} \mathrm{\supset}$ "piy" derives from the word pimatisiwin, meaning "Life." Nipiy is thus properly understood as meaning "I am Life." Water is lifeblood, animating us as human beings, and all that is around us. The Cree language operates on the principle of anima, life-force. Understanding that elements of ourselves and our environment(s) have an inner life force determines how those elements are described, usually in a relational manner. Water is as much a process as it is an entity. Water has so many identities in our language - over 40 words or phrases in Cree describe water in all its forms and manifestations. Water is a living, cultural and spiritual entity that defies reduction to a mere resource.

Water finds a place in the Cree History of Creation Stories, ceremonies, and laws regarding human interaction with water. There are people in Cree society who hold special responsibilities for water. For instance, women are life givers and, as such, hold a sacred status for this ability, which translates into related roles in gender-specific ceremony, song, dance, and oral knowledge. Collective responsibilities also arise out of Indigenous legal orders, practices, and protocols respecting water management, collection, and use. Accordingly, water can shape identity much as it shapes land and rock. The spirit of water flows through and among peoples, family, and individuals to contribute to the dynamic structures of culture, language, legal orders, and landscapes. The presence of spirit in water and its place in our lives is tied to the way Cree legal traditions describe rights and duties affiliated with water. ${ }^{101}$ Drawing on these Cree legal principles, Danika identifies frameworks, procedures, and remedies for creating better water management systems in her area of study. She does this by comparing and contrasting Cree law with Canadian constitutional law along with provincial and federal law and policy. The thesis demonstrates how learning law from the land and water within a specific First Nation tradition can generate creative solutions to meet our contemporary legal needs.

Secwepmec lawyer Nancy Sandy was an Master's of Law student at UVic at the same time as Danika. Nancy also spent a significant amount of time learning from, and being on, the land during her graduate studies. She did this by working with ten Elders in her own community to learn how they taught and applied their laws. Nancy is a former Chief of the Williams Lake Indian Band in central

99 Danika Billie Littlechild, "Transformation and Re-Formation: First Nations and Water in Canada" (LLM thesis, University of Victoria, 2014) at 14 [unpublished].

$100 \quad$ Ibid at 27.

101 Ibid at 19, 20, 24. 
British Columbia. Her research was designed to highlight the contours of the Secwepmec legal order related to child safety. She has an intimate knowledge of how federal, provincial, and common law regimes are failing her people in this area. After speaking with her Elders, Nancy's central argument is that the growth and application of Secwepmec law could build stronger, healthier, and progressive Secwepmec families. She makes a strong case that Secwepmec laws are foundational to the Nation's constitutional, legislative, and adjudicative powers related to child welfare. She does this by showing how Elders' stories about the land are a key to the revival of Secwepmec nationhood.

Nancy heard many land-based references related to how a person or community might learn from these observations and, thus, better work towards meeting their legal obligations and opportunities. She observes that "the St'exelcemc learned to find and develop law from their observations of the physical world around them - looking at how each part relates to the other. From these observations we developed rules and regulations. We have conflict resolution that is literally drawn from and written on the land." ${ }^{102}$ In illustrating this point, she provides illustrative examples, like the following story:

A long time ago the brother chickadee was playing with his little sister and he got annoyed with her and hit her or yelled at her. So she went away into the forest, and you know, the animals and the birds talk in Shuswap. So, now when you go in the forest you can hear the little brother chickadee saying [participant whistled like a chickadee] and it sounds like tsetsé7 (which means little sister in Shuswap). The moral of the story is "be good to your littler sister" I guess. ${ }^{103}$

Nancy concludes: "The story of the careless chickadee captures how the St'exelcemc passed on their law of caring for one another through story-telling." Nancy's research at home on the land contains many such lessons. It illustrates the importance of listening to Elders as they relate what they have learned about law from being on the land to develop a legal literacy that she could not find in law schools.

Trudeau Scholar Aaron Mills also looks to the land to learn to understand and apply Indigenous law. ${ }^{104}$ After graduating with a law degree from the University of Toronto law school and subsequently receiving an Master's of Law degree from Yale University, Aaron enrolled at the University of Victoria for his doctoral studies. Over the past two years, Aaron completed his course work and successfully defended his doctoral proposal. During his time at UVic, Aaron also significantly enhanced his knowledge of Anishinaabe law by studying hundreds of primary and secondary sources about Anishinaabe law. He knows the "law in the books" as a result of this work. Aaron also participated in Anishinaabe language tables, Anishinaabe storytelling circles, and other community-based activities to ensure his education was attentive to learning law outside the law school's formal curriculum.

Aaron is from the Couchiching First Nation in northwestern Ontario, and he is now living in his home territory. He is intensively learning and practising Anishinaabe law from and on the land under the steady guidance of Anishinaabe Elders. As he writes his doctoral dissertation, he is focusing on how "right relations" are formed through understanding the place-based nature of Anishinaabe law. These

102 Nancy Sandy, "Reviving Secwepemc Child Welfare Jurisdiction" (LLM thesis, University of Victoria, 2011) at 147, <https://dspace.library.uvic.ca/bitstream/handle/1828/3336/Sandy_Nancy_LLM_2011.pdf;sequence=1>.

103 Ibid at 74.

104 Wapshkaa Ma'iingan (Aaron Mills), “Aki, Anishinaabek, kaye tahsh Crown” (2010) 9 Indigenous LJ 107. 
"grounded" activities are designed to assist him in completing his degree. Some of these activities, which were identified in his doctoral proposal, are described as follows:

I also intend to acquire knowledge about Anishinaabe constitutionalism specifically and our legal tradition generally through Anishinaabe means. ... A few examples of activities ... which I have already or may in future involve in my dissertation are as follows:

- taking dreams seriously;

- I did a bawajigaywin (vision quest) this summer on Anishinaabe territory under the care of John Borrows;

- participation in ceremonies such as a sweat lodge, ... pipe ceremonies and feasts;

- sometimes using my mitiginaabe (talking stick), Eagle Feather, and Headband when acquiring or processing knowledge;

- drumming (some of my songs are explicitly about relating well with others);

- Manoominike (making wild rice);

- the Woodlands School of Anishinaabe art visually represents cosmological relationships and ontological understandings. I'll engage, in particular, with some works of Norval Morrisseau;

- Bannock Point and Tie Creek are sacred sites in Manito Ahbee (in Whiteshell Provincial Park, Manitoba) that contain petroforms. There are extremely important teachings about right relations here which go directly to Anishinaabe constitutionalism....

- there are treaty and other teachings in the pictographs in Lake of the Woods and in Rainy Lake. I expect that pictographs in Quetico may have similar teachings. ... I also wish to visit the great rock painting of Mishibizhiw at the Agawa site, Lake Superior.

Aaron is consciously developing his understanding of the distinctive legal methodologies of Anishinaabe peoples described earlier in this article: gikinawaabiwin/akinoomaagewin. He is learning law from the earth through Elders, stories, songs, ceremonies, and hundreds of formal and informal interactions with Anisihinaabe teachers who understand that analogies can be drawn from our natural surroundings and applied or distinguished from human activity. As noted earlier, in this legal approach, the environment becomes the legal archive. Aaron is learning how to read and use this knowledge as part of Anishinaabe communities' self-regulation.

Furthermore, the bawaajigewin that Aaron references in his doctoral proposals illustrates another specific method about how Anishinaabe/Indigenous law can be learned from the land. Within Anishinaabe legal tradition, it is important for practitioners to reflect upon their responsibility for themselves, families, communities, and the wider world. This is often done after a period of extensive preparation and study under the guidance of Anishinaabe teachers. In this case, I helped Aaron work towards and complete this task. His "articling" period was an entire year where he learned from rocks 
(assinig), plants (tobacco, sage, cedar, and sweetgrass), birds and animals (drums, bundles, and songs), seasons, and other elemental substances.

\section{CONCLUSION}

Experiences learning law from and on the land are recorded in constitutions, statutes, regulations, bylaws, declarations, adjudicative judgments, songs, carvings, textiles, dances, wampum belts, scrolls, petroglyphs, and so on. Stories are also an important vehicle for recording such laws. ${ }^{105}$ In her Master's of Law thesis, Scewepmc lawyer Nancy Sandy put it this way: "Law is also embedded in stories. Like common law cases, they could communicate appropriate and inappropriate behavior. Stories could also record punishments, or chronicle when mercy or justice was extended or retracted." ${ }^{106}$ Hadley Friedland, who worked with Cree stories in both her master's and doctoral theses, similarly observed that these stories could help students attend to law "on the ground" within Indigenous communities. ${ }^{107}$

The Indigenous Law Research Unit [ILRU] at UVic focused on stories as a resource for legal reasoning and practice. The ILRU has worked with band councils, Elders, hereditary chiefs, clan mothers, and other customary structures to understand these legal traditions. Law students, lawyers, judges, and legal academics have worked with these individuals and groups to "honour the internal strengths and resiliencies present in Indigenous societies and in their legal traditions, and to identify legal principles that may be accessed and applied today - to governance, lands and waters, environment and resources, justice and safety, and building Indigenous economies." 108 Val Napoleon who is the director of ILRU has done ground-breaking work in bringing Indigenous law more fully to light. Legal education that attends to other dimensions of Indigenous law is being developed by other law professors across the country, and their varied approaches are vital to this work.

The information contained in this article are examples of what law schools, legal educators, and governments might do to fulfil the recommendations of the Indian Residential Schools Truth and Reconciliation Commission. Recommendations 27 and 28 call for law schools to create a course in the laws related to Aboriginal peoples, skills-based training in intercultural competency, conflict resolution, human rights, and anti-racism. ${ }^{109}$ Recommendation 50, under "Equity for Aboriginal People in the Legal System," calls upon the federal government "to fund the establishment of Indigenous law institutes for the development, use, and understanding of Indigenous laws and access to justice."110

105 Jacquie Green Kundoqk, "Transforming Our Nuuyum: Contemporary Indigenous Leadership and Governance: Stories Told by Glasttowk askq and Bakk jus moojillth, Ray and Mary Green" (2014) 12 Indigenous LJ 33.

106 Sandy, supra note 102 at 89.

107 Hadley Friedland, "Reflective Frameworks: Methods for Accessing, Understanding and Applying Indigenous Laws" 201111 Indigenous LJ 1.

108 Indigenous Law Research Unit, <http://www.uvic.ca/law/about/indigenous/indigenouslawresearchunit/>.

109 Truth and Reconciliation Commission, "Calls to Action" (Winnipeg, MB, 2015) at 3, <http://www.trc.ca/websites/trcinstitution/File/2015/Findings/Calls_to_Action_English2.pdf>.

110 Ibid at 5-6. 